\title{
RESPONSE
}

\section{A Contribution to the Conversation}

\author{
Mike Mtika
}

This very interesting research by Priest, Ngolo and Stabell (2020) seems to be a case study of the work of the Church vis-à-vis child-witches, with EPED coming in to counter absurd child-witch deliverance activities by the Church. The research deals with the what question; it does a wonderful job here. On the other hand, it does not seem to engage in the why question. Perhaps this is for future research. I think digging into the why question would help address the roots or foundations of child-witch accusations and deliverance schemes. Focused on the what questions, addressing the matter is understandably rooted in the absurdity of the practice rather than its root causes. The important unanswered questions that stand out to me include what exactly has led to the involvement of the Church in legitimating child-witches accusations and deliverances? Is it revivalism? Is it the rise of prophesying in the Church and why such a rise? The research is silent on this thus leaving the reader to take misfortunes as the foundation of child-witches and the resulting involvement of EPED in helping the Church to deal with the issue.

More specific to the matter, the authors state, "central to the new and emerging cultural patterns is the identification of children as the locus of witch agency and harm" (33). This is definitely a worrying situation that the children may be the locus of witch agency in the Democratic Republic of the Congo; it may not be so in other places. In Malawi, my country of origin, there is a common belief that adult witches use children in their witchcraft. Specific to the children issue, how exactly do children become witches; how do they emerge and acquire these witchcraft powers? How is it that the signs that identify witches have attained the seemingly sacrosanct role in identifying child-witches? In the case of Berthe, what is it about bed-wetting, talking in her sleep, and poor health (35) that is witchy; how come people have accepted these as evidence that she is a witch? Further, the authors write "while most pastors' understandings of witchcraft in all likelihood do not differ fundamentally from the understandings of Kinshasa's population as a whole, pastors nonetheless play central authority roles in justifying, reformulating, and socially transmitting the complex of ideas related to child witchcraft" (38). Again, authors write, "African churches have been central both in propagating child- witch ideologies, and in working to resist child-witch ideologies, accusations, and deliverance practices" (38). What is the origin of these pastors' views? What has pushed the churches into this behavior? What is sustaining this behavior? I think the research does a wonderful job of describing what is going on and what EPED is doing, but seems to be circumventing the root of child-witch accusations. The proposed ways of addressing the matter thus tend to focus on the absurdity of accusing children as witches. I think we get trapped into similar problems of the 1800s and early 1900 s. Missionaries condemned certain behavior on the basis of the absurdity of the behavior. There was little reasoning given to complex situations or the sociocultural underpinning of the behavior. Female genital mutilation is an example of an absurd pointless practice, and the argument to stop it on the basis of its absurdity is valid. However, an understanding of the socio-cultural context behind the practice followed by engaging the people to re-shape that socio-cultural meaning would bring the needed, insightful, and sustainable change.

I find it very interesting that the authors argue for engaging in discussions concerning "hybridities of meanings, categories, assumptions, actions, and intentions indebted to some combination of Scripture and culture" (40). Many other items for engagement are proposed. Great work. Hybridities must take us to the root of behavioral practices. I cannot tell, from the research, what is behind child-witch accusations and the legitimacy the Church gives to this. It seems misfortune is a main factor in these accusations. Why have misfortunes had such an influence, why have the signs been accepted as evidence of witchcraft, and why has the Church engaged in the legitimation of child-witch accusations? These remain unanswered questions.

I must make an observation before proposing an alternative insight into the witchcraft matter. I think the shamans, traditional healers, and witch doctors the authors discuss (cf. 10) refer to different situations at least in the case of Malawi, my country of origin. A traditional healer or traditional doctor is one who knows traditional medicine (herbs and such other stuff) used to heal someone suffering from all sorts of illnesses. There is a whole hierarchy of them. One 
traditional healer may refer a patient to another regarded more knowledgeable on a particular illness. The witch doctor is one who does engage in traditional healing but is also able to defeat witches; he or she has power over the witches. I think witch doctors are similar to shamans except that in the case of shamans there may be no connection with witches. Thus, witch doctors may tell who is a witch or not while the shaman can only talk of evil things that a person is experiencing. The pastors in the Congo engaging in telling who is a witch from a spiritual perspective seem to be combining "shamanism" and "witch doctoring".

My proposed view-witchcraft can be understood from its supernatural influence rooted in the sociocultural context and the sinful heart, for all of us "have sinned and fallen short of God's glory" (Romans 3:23). Jesus was tempted to change stones to bread at a time he very much needed food. He was able to do this, but doing so entailed falling into the evil one's deception. People in Lystra thought Paul and Barnabas were gods; they could have accepted the labels and become famous. However, Paul and Barnabas reacted by tearing their clothes and telling people they were not gods (Acts 14:11-15). We see situations in society where people are drawn to those claiming supernatural influence over something (illness, protection, riches, fame, witchcraft, spiritual discernment, etc.). Witch doctors have had such influence. For Malawi, Soko (1987) and Kalinga (2011) report of Nchimi (Witch Doctor) Chikanga, a famous witch finder who operated in northern Malawi during the 1950s-60s. There was Simbazako, also a famous witch finder operating in the central region of Malawi in the 1970s-80s. There have been many similar witch finders and "protectors" from witchcraft. All claim to have supernatural power to find witches but also protect people from being bewitched. Similarly, so called "men and women of God", as has been the case with witch doctors, draw people on the promise of miracles that they can engage in through prayer or other spiritual practice. There is a human tendency towards such supernatural stuff. So called "men and women of God" are falling into the deception by the evil one. If they engage in something supernatural like delivering a child believed to be a witch, they get the honor, money, fame, etc. It happens outside the Church; it has invaded the Church not only in places like Kinshasa but all over the world. I have had a good share of dialogue with such "men and women of God"-who are basically acting like witch doctors-claiming to have some supernatural influence. This is the problem of the Church not only in Kinshasa, but worldwide.

A correction: the authors write, "While the concept of a high God was common in many African societies prior to the presence of Christianity, the concept of a Satan figure, of a powerful and evil supernatural being as the discursive focus of evil, as the opponent of God and the good, the leader of a host of demonic beings similarly inclined, was absent . . Ancestral spirits and nature spirits were often understood to exist, but were not understood as ultimate opponents of God or the good" (41). I have little knowledge of insightful anthropological studies on the matter but it seems to me that the matter of good versus evil and the hierarchy in the good and in the evil have been realities in the Malawi culture that I am familiar with. They may not have used terms like Satan but that there was some hierarchy in both the good and the evil world was apparent. The argument that the "witch's power was understood as personal and psychic or magical, but was not normally thought of as power derived from sentient nonhuman spirits" (41) does not seem to represent the understanding people have of witchcraft in Malawi. People talk about demon-possessed, that an evil spirit has entered someone. Such contexts of understanding sets the power of good (God) against evil (devil) in the supernatural non-human world.

\section{References}

Biblical references are from the 2008 Crossway English Standard Version Study Bible.

Kalinga, Owen J. M. 2012. Historical Dictionary of Malawi (p. 124). Toronto: The Scarecrow Press, Inc.

Priest, Robert J., Abel Ngolo and Timothy Stabell. 2020. Christian Pastors and Alleged Child Witches in Kinshasa, DRC. On Knowing Humanity Journal 4(1):1-51.

Soko, Boston. 1987. Nchimi Chikanga: The Battle against Witchcraft in Malawi. Zomba, Malawi: Kachere Books.

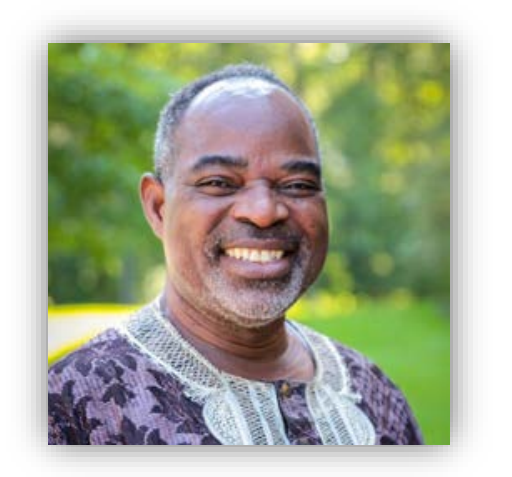

Mike Mtika: BSc in Agriculture (1978) from Bunda College of Agriculture, University of Malawi, now Lilongwe University of Agriculture and Natural Resources; MSc in Agricultural Extension and 
Rural Development from Reading University in United Kingdom (1980); and PhD in Sociology from Washington State University (1998). Expertise in rural and community development. Research focus: (a) political economy of HIV/AIDS and (b) how people draw upon capital to improve their wellbeing. Worked as an Agricultural and Rural Development Officer in the Ministry of Agriculture in Malawi (1978-1986). Joined World Vision (Malawi) and worked for the organization starting as a Projects Coordinator in 1986 and ending as Technical Services and Operations (Projects) Director in 1991. Currently Professor of Community, Economic, and Political Sociology at Eastern University. Also, Founder and Director of Field Operations of Pamoza International, a non-profit organization involved in Christian Outreach and Community Development in northern Malawi.

Author email: mmtika@eastern.edu 